\title{
THE ROLE OF CLICHÉS IN CONTEMPORARY DIGITAL AUDIOVISUAL ARTS
}

\author{
Mihael Konstantinov \\ University of Haifa, Israel \\ mih112344@gmail.com \\ The article was created as part of a postdoctoral project \\ in the University of Haifa.
}

In this study, I analyze the role of clichés in contemporary digital audiovisual arts. The use of clichés in the author's high art is considered to be a manifestation of a low artistic level. But the same use of clichés in folklore and popular art is not considered to be a "primitive" performance. Clichés in art are defined as a formula. The article presents an approach to formulaic art by John G. Cawelti and Juri Lotman. This approach is the methodology of my study of the role of clichés in the creation of virtual space and hyperreal fictional world. Since clichés play a very important role in contemporary popular culture, I present the data by Lev Manovich, the researcher of digital visual culture. He analyzes the digital component in the digital audiovisual medium. Thus, for the first time, I link Cawelti and Manovich in the analysis of contemporary digital audiovisual art. Speaking about the digital component in art, I should mention that the interface, defined as a formulaic construction, is its important feature. The article states that the cliché in modern digital audiovisual art is one of the main structural elements of a work of art which affects the aesthetic form and content of an audiovisual work. Using clichés, we create virtual and hyperreal worlds that help the addressee to feel escapist feelings and get immersed in these fictional worlds. Also, clichés give us the opportunity to see the new in the already familiar in the perception of art. I define the vision of "new in the already familiar" as defamiliarization by Viktor Shklovsky. The listed properties of the cliché are manifested in all digital contemporary audiovisual arts: cinema, video games, video art, and video installation. The examples are given below in the study. The obtained results are relevant for studying the new types of digital audiovisual arts such as Internet art, interactive cinema, science art, computer art, and others. These arts are now at the stage of their formal, aesthetic and content formation. The obtained results will help to understand the new processes taking place in our postmodern society.

Keywords: cliché, formula, formulaicity, Cawelti, Lotman, popular art, audiovisual arts, hyperrealism, Baudrillard, postmodernism, virtual space, End of Art, Manovich. 


\title{
РОЯЬ КАИШЕ В СОВРЕМЕННОМ ЦИФРОВОМ АУ ДИОВИЗУАЯЬНОМ ИСКУССТВЕ
}

\author{
Михаэль Константинов \\ Хайфский Университет, Израиль \\ mih112344@gmail.com
}

В данном исследовании анализируется роль кдише в современных цифровых аудиовизуальных искусствах. Клише в искусстве может определяться как формула. Основываясь на подходе к формульности Джона Кавелти и Юрия Лотмана, мы анализируем роль клише в формировании виртуального пространства и гиперреального вымышленного мира, которые являются характерной особенностью культурной парадигмы постмодернистского общества.

Так как клише играет важную роль в современной массовой культуре, мы приводим данные исследователя цифровой визуальной культуры Иьва Мановича, который анадизирует цифровую составляющую в цифровом аудиовизуальном медиуме. Тем самым впервые мы связываем подход Кавелти и Мановича в анализе современного цифрового аудиовизуального искусства. Говоря о цифровой составляющей в искусстве, следует упомянуть ее важную характеристику, которой является интерфейс, определяемый нами как формульное построение.

Клише в современном искусстве является одним из главных структурных элементов художественного произведения, который влияет на эстетическую форму и содержание аудиовизуального произведения. При помощи кдише мы создаем виртуальные и гиперреальные миры, которые помогают зрителю почувствовать эскапистские чувства и погрузиться в эти вымышленные миры. Также клише дает нам возможность увидеть новое в уже знакомом при восприятии искусства. Видение «нового в уже знакомом» мы определяем как прием «остранения» Виктора Шкловского. Перечисленные свойства клише проявляются во всех цифровых современных аудиовизуальных искусствах кино, видеоигры, видеоарта и видеоинсталляции, примеры которых мы приводим в нашем исследовании.

Ключевые слова: клише, формула, формульность, Кавелти, Лотман, массовое искусство, аудиовизуальное искусство, гиперреализм, Бодрийяр, постмодернизм, виртуальное пространство, Манович.

DOI 10.23951/2312-7899-2021-2-43-62 


\section{Introduction}

Depending on the emphasis in the analysis of the formulaicity, there can be distinguished two groups of researchers: the first group focuses on the repetition of elements in the syntagmatic chain of artistic and poetic text - Milman Parry, Albert B. Lord (the Parry-Lord theory), Viktor Shklovsky, and others. The second group focuses on the structural construction of an artistic text, which determines its artistic genre. This group is represented by John Cawelti, Juri Lotman, and others. In this study, I focus attention on the second group of the researchers of formulaicity.

In 1928 Milman Parry, while researching the works of Homer, introduced the term formulaicity into academic discourse, although the very concept of formula as locus communis (common place) in an artistic text has long been well known and refers to ancient rhetoric and medieval literature. By the formula Parry understands: “... a group of words which is regularly employed under the same metrical conditions to express a given essential idea" [Parry 1971, 272]. His disciple and follower, Albert Lord, adds to this definition: "By formulaic expression I denote a line or half line constructed on the pattern of the formulas. By theme I refer to the repeated incident and descriptive passages in the songs. $<\ldots>$ The formulas are not the ossified clichés which they have the reputation of being, but that they are capable of change and are indeed frequently highly productive of other and new formulas" [Lord 1971, 4]. The Parry and Lord approach is called the Parry-Lord theory. John Cawelti extended the notion of formulaicity to include narrative schemes: "In general, a literary formula is a structure of narrative or dramatic conventions employed in a great number of individual works. $<\ldots>$ Thus formulas are ways in which specific cultural themes and stereotypes become embodied in more universal story archetypes" [Cawelti 1976, 5-6]. The formula characterizes the type of plots and determines the genre of a work of art.

The formulaic structure is typical exactly for popular art. The author's high art and formulaic works of art constitute two opposite poles of art [Cawelti 1976, 13]. Cawelti points out the fact that formulas (clichés) are based on cultural plot archetypes and are able to satisfy a person's need for entertainment and escape from reality [Cawelti 1976, 6]. The addressee knows the formula constructions, so they know how everything is going to end. In such a situation, the addressee gets satisfaction and rest. Cawelti concludes that formulaic art is characterized by escapism [Cawelti 1976, 14-15]. This feature of popular art is also pointed out 
by Umberto Eco, saying that familiar and repetitive plots give the reader an opportunity "in a withdrawal from the tension of past-present-future to the focus on instant, which is loved because it is recurrent" [Eco 1984, 120, Eco's italics].

John Cawelti considers the idea that escapism in formulaic art is achieved through three artistic techniques: suspense, identification and the creation of an imaginary world that is slightly modified from the real world. The author needs suspense in order to arouse a temporary feeling of fear and uncertainty about the character that is dear to us. The simplest model of suspense is a gripping narrative in which the life of a protagonist is in mortal danger and the mechanism of their salvation is hidden from our eyes. We know, however, that the character will be saved, as it always is. Alfred Hitchcock is well known for his ability to create such suspense.

In the formulaic work, the main character is usually better and more successful than the addressee. Therefore, recipients usually identify themselves with a "better person" than themselves. Carried away by the course of action, the author of the formulaic work avoids the need for a more complex portrayal of characters, as it is customary in the author's art. Therefore, stereotypical characters reflecting the audience's established life and society views are used there. [Cawelti 1976, 18-19].

Cawelti states that in order for the addressee to dive deeply into the imaginary world of the work, it is necessary that this world be based on principles that are understandable to them. That is, the world is recognizable, but it is "slightly modified". Due to the fact that formulas express generally accepted norm and understanding in society, the imaginary world in a formulaic work of art is always closely connected with the real world [Cawelti 1976, 19].

All the properties of narration that I have enumerated in formulaic art coincide with the properties of storytelling in folklore. Vladimir Propp, characterizing folklore, proves that in folklore the narrative is characterized by exceptional dynamism of action [Propp 1984, 22], which is expressed in the addressee's tension and worrying as well. In folklore narration, we do not see detailed descriptions of characters or locations. The emphasis is on the action itself and its detailed description: "The narrator or singer and the listener are interested only in the action and nothing more" [Propp 1984, 21]. In a fairy tale, unusual stories are told as if they happened in the real world: "The story has been transformed into a 'true' one" [Propp 1984, 20]. Here we see the closeness of formulaic art to folklore and oral tradition. 
Formulaic art involves the application of strict different rules or formulas that can be thought of as a canon. Speaking about the types and stages of art development, in which observance of generally accepted rules and norms prevails, Lotman refers to aesthetic of identity, which consists of identification and improvisation (1970). Aesthetic of identity is characterized by the use of various clichés that are well known to the author and the addressee. Lotman shows that aesthetic of identity: "is based on the total identification of depicted phenomena of life with model-clichés that are known beforehand to the audience and operate according to a system of 'rules' " [Lotman 1977, 290], when this cliché itself does not diminish the artistic value of the work of art [Lotman 1977, 290]. The peculiarity of improvisation in aesthetic of identity is that its elements are known in advance to the addressee: "the improvisation itself is not an unrestrained flight of fantasy, but a combination of elements known to the spectator" [Lotman 1977, 291].

How is a good piece of art created using various clichés? In answering this question, Lotman refers to the "Greek and Tatar hack" by Viktor Shklovsky. Lotman thinks that the cinema of the 1920s often took a literary work of high art as a basis for the script and translated it into "everyday language" of an average cinema spectator. And this was done using cinematic clichés [Lotman, Tsivyan 1984, 68-69]. In the "hack" we see the use of folklore (formulaic) way of narration Cawelti and Propp mentioned above. Therefore, "hack" is a formulaic construction.

Lotman says that cliché is a characteristic property of cinematography that crystallizes the filmic form of the cinema language, while the cliché itself is filled with the myths of mass consciousness [Lotman, Tsivyan 1984, 60, 62, 64]. Gilles Deleuze also speaks of cliché as characterizing contemporary cinema; however, unlike Lotman, he critically evaluates the role of cliché in cinema. Deleuze says: "A cliché is a sensory-motor image of the thing" [Deleuze 1989, 20], and it indicates a crisis situation in cinema, namely, an action-image crisis (Deleuze's term): a break in sensory-motor connections, chronology and consistency between "portions of space". As a result of all this destruction, the use for a set of various clichés begins, which should denote many different actions of the characters and phenomena in the film. [Deleuze 1986, 208-209]. Moreover, when the viewer perceives the film, first of all, it is the clichés that are perceived [Deleuze 1989, 20]. Therefore, Deleuze, speaking of modern cinema, exclaims: "Nothing but clichés, clichés everywhere ..." [Deleuze 1986, 208, Deleuze's italics]. This description of Deleuze characterizes postmodern cinema very well. 


\section{Formula - Mythologism - Virtuality}

A cliché is a mental image made up of concepts and images. Deleuze refers to the mental image as a relation-image. The relationship is between generally accepted norms (Deleuze's series) and their violations [Deleuze 1986, 203-204; Deleuze 1989, 33]. Formulas define these relations as generally accepted ways of presenting and correlating certain images, symbols, themes, and myths. The formula is an integral part of the mythological world. The mythological world itself is very different from the real world. There is no linear development in this world, according to which the present follows the past and the future comes after the present. In the mythological world, cause-and-effect relationship is broken, which violates the logical connection of linear development and the narrative has a rhizomorphic development. The mythological world is characterized by the autonomy of time and space, and it has a "fragmentary character". Any object of the mythical world, getting to a new place, loses all its previous connections and thus creates a modeling of new relations, and the object undergoes qualitative changes. This situation is typical for film editing, namely the Kuleshov effect. Therefore, cinema, like all audiovisual art, in my opinion, is an art with mythological thinking.

The virtual world appears with the development of communicative and electronic technologies. This world resembles the mythological world. Analyzing virtual reality, we can list all the properties of the mythological world that have been mentioned. The virtual world evokes escapist feelings in us. Earlier I have said that, according to Cawelti, in order to evoke escapist feelings, the fictional world must be based on the real world. This means that in order to immerse in the virtual world, it must be based on principles that correspond to the real world. This is achieved through formulas.

The virtual world is characterized by hyperreality, which enhances the addressee's immersiveness. One of the ways to create a hyperreal space is to accurately copy and replicate images of objects in our reality. Jean Baudrillard says that with multiple copying of images of an object, the sign is freed from its referent and its meaning, and refers us to a new reality that has nothing to do with the real world [Baudrillard 1993, 69; 71-72]. This reality is hyperreality. We see an example of such replication, first of all, in audiovisual advertising. For example, in TV advertising, where a certain cliché (the image of an object) is associated with a certain narrative in its commercial, and, after a certain period of time, 
we again see the image of this cliché itself, then we immediately recall its entire narrative story in TV advertising. These clichés acquire a stable narrative content like mythological archetypes, and they become cultural symbols of the era and narrative archetypes that create formulas. It turns out that hyperreality consists of formulas.

Advances in technology played an essential role in hyperreality creating. Thus, high-definition technology (HD) shows the smallest details of the object in the image. A huge number of such small details showing the object cause a strong sense of reality feeling for the addressee, but at the same time the object itself (referent) is lost from the field of view. Its many details become more important than the object itself. Such a world is characterized by fragmentation. This creates an artificial "high definition" hyperreality, which draws us into its space. As examples, I want to cite the filming of military parades in different countries. All of these parades were filmed with maximum high definition (HD) technology. In Russia, China, North Korea, the emphasis when filming military parades is given to the presentation of the invincible army: complete synchronization of all actions, which is expressed in views, steps, synchronous movement of all units and shouts of participants. The attention is also paid to the movement of the camera, and the lower point of the shooting which increases the significance of the object being filmed: close-ups of faces, legs, guns, etc. And all this comes in large quantities. Military parades or other mass events from year to year are filmed strictly according to the same patterns, which are formulas. These formulas create a visual national mentality of the viewer in their attitude to these events.

\section{Author's and popular art today}

It is customary to divide art into "high" - author's, and popular mass. The American art philosopher Arthur C. Danto, examining the works of Marcel Duchamp and Andy Warhol, applied the Hegelian expression End of Art, which I understand as the end of high art. The author's art is based on traditional aesthetic ideals and this is a necessary condition for "high" art. For contemporary popular art, it did not become a critical moment of its existence: "contemporary art is hardly aesthetic at all" [Danto 2013, 155]. Danto notes that, in modern art, objects of art are almost indistinguishable from objects of reality and therefore there is no room for art: "One argument for the End of Art is 
that it rests on the fact that art and reality are in certain cases indiscernible" [Danto 2013, 49]. In my opinion, the American philosopher means the absence in the works of Duchamp and Warhol of the semiotic concept of Convention in Art, which is a necessary condition for the classical understanding of art. "Convention in Art is the realization in artistic creation of the ability of sign systems to express the same content by different structural means" [Lotman, Uspensky 1998, 374]. When we talk about the exact copy of a real object in an artistic image, we thereby deny the variability of displaying this object in a work of art. In contemporary art, this Convention in Art has been destroyed. The world of art becomes the world of reality - hyperreality. The works of Duchamp and Warhol are united by an absolute similarity of the artistic image with the objects of real world and their replicability - i.e., cliché. Marcel Duchamp has a cliché-based mass-produced product - the urinal Fountain (1917), Andy Warhol has a cliché-stencil for the production of boxes Brillo Box (1964) and other works of art. See Fig. 1.

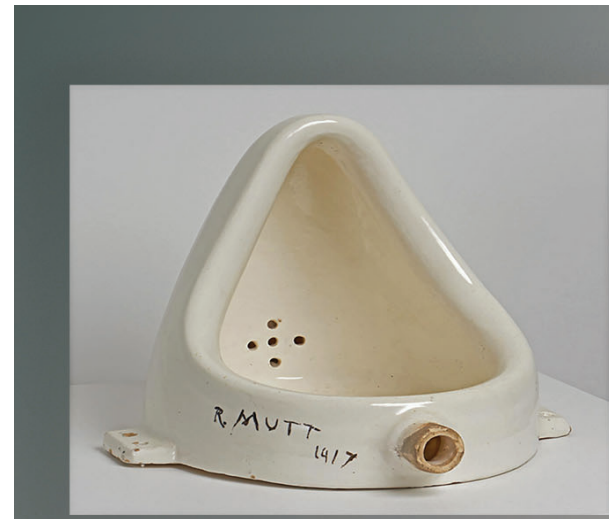

Marcel Duchamp "Fountain" (1917)

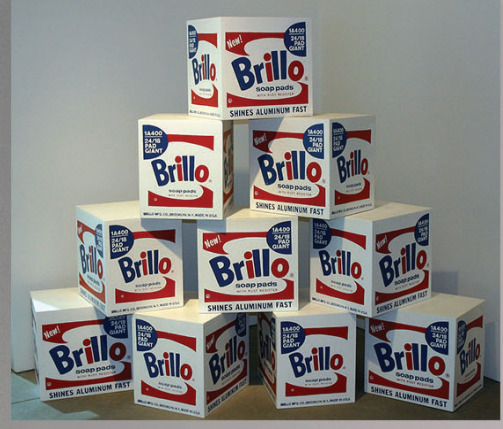

Andy Warhol

"Brillo Box" (1964)

Fig. 1. Examples of clichés.

Photos from open sources: https://player.slideplayer.com/90/14544703/slides/slide_6.jpg; https://d2jv9003bew7ag.cloudfront.net/uploads/Marcel-Duchamp-Fountain5.jpg

Agreeing with Danto that the "author's art" has ceased to exist, I state the fact that today contemporary art is a popular art. And this art is characterized by the use of formulaicity, as I have indicated above. 


\section{Clichés in contemporary audiovisual art}

Clichés in the cinema

The film researcher Oleg Aronson states that after the 1970s auteur cinema ceased to exist [Aronson 2013]. Therefore, modern cinema, as a popular art, is characterized by the abundance of formulas. The contemporary director Andrey Zvyagintsev says that cliché is a kind of a corridor with no opportunity to "jump out" but he is trying to expand it in his works [Zvyagintsev 2014]. Expanding the corridor is not leaving it. Aronson attaches great importance to the role of cliché in cinema, and he calls the discoverers of these clichés "film geniuses": "... a genius is not the one who creates something original, but the one who discovers the cliché. That is, genius reveals something that everyone uses, that affects the viewer flawlessly, despite the fact that this cliche is repeated hundreds of times, but does not refer to the discoverer"[Aronson 2003, 252, Aronson's italics]. As an example, Aronson calls the directors that are "film geniuses": Griffith, Vertov, Eisenstein, Renoir, Wells, Antonioni, Fellini, Bergman, Godard, Tarkovsky. Aronson defines clichés as: "images that are located in terms of the immanence of the cinema itself. $<\ldots>$ Film genius (by means of clichés - note by M. K.) <...> creates an image that does not supplement expressive possibilities, but allows, through cinema, discover a thought where we did not know it before" [Aronson 2003, 253], i.e., the new meaning. I believe that the "new meaning" that reveals by means of a cliché (image) is defamiliarization by Shklovsky, its idea is to carry the addressee away from the automatism of perception.

An example of formulaic art is the work of the largest contemporary filmmaker Quentin Jerome Tarantino. In an interview to EMPIRE (1994/65), Tarantino said: "I steal from every single movie ever made. $<\ldots>$ If my work has anything, it's that I'm taking this from this and that from that and mixing them together" [Tarantino 1994, 87]. Tarantino's films are formulaic works of popular art, full of various borrowings from other works of art. These borrowings themselves represent intertextual relations in the global textual culture. Tarantino, referring to borrowings from other films, does not transfer them in their original form into his films. Firstly, in one of his films he refers to several sources of his borrowing and then "stitching them together" creates something new and stylized. This technique is called Pastiche and, together with intertextuality, characterizes postmodern art, which is dominated by the opinion that there is absolutely nothing new in contemporary art, but everything has its original source [Jameson 1983, 113]. Tarantino makes 
borrowings in three stages: copying (Tarantino appeals to many primary sources of borrowing in one of his films), transforming (Tarantino's Pastiche) and combining (original vision, as well as Tarantino's screenwriting and directorial skills). These three elements - copying, transforming and combining - can be called the methodology of the creative process in the whole postmodern art.

Tarantino's films are focused on reproducing the traits of certain genres in cinema: Reservoir Dogs (1992) is a pastiche of violent Hong Kong action films, especially City On Fire (1987). The film Pulp Fiction (1994) is focused on films of the groundbreaking French New Wave that challenged the classic traditions of film language. Films Kill Bill 1-2 (2003-2004) are stylized as classic Japanese samurai films and Chinese kung fu films. The film Inglourious Basterds (2009) is based on the World War II films The Dirty Dozen (1967) and The Searchers (1956). In the films Django Unchained (2012) and The Hateful Eight (2015), we see a modern adaptation for the Italian Spaghetti Western. It can be concluded that Tarantino's films are, in fact, secondary adaptations of classic films and genres, their action takes place in the director's unique artistic world.

It was not the main goal for famous modern filmmakers just to copy all kinds of films. If we remove all these borrowings, their films as works of art will take place at some minimal semiotic level. It means that they have a fairly coherent structure without quotation, allusion, homage from other films and works of art. Viewers who are not familiar with these primary sources will not feel that they are missing something when they perceive the film. Nevertheless, these borrowings are extremely important for the director to express his entire intention. For example, Antichrist (2009) directed by Lars von Trier is an allusion to Andrei Tarkovsky's Mirror (1974). Despite the differences in the aesthetics of these films, a comparison of the scenes in them leads to the conclusion that the film Antichrist is a kind of a mirror reflection of the film by the Soviet director, i.e., Anti-Mirror. The film by Tarkovsky focuses on the expectation of a new life, hope and salvation, while Lars von Trier's emphasis is on death and hopelessness, madness and apocalypse.

I want to put forward one more assumption, as a hypothesis, on the reasons for borrowing in contemporary audiovisual art. As I have indicated above, Baudrillard believes that copying the object of reality and its replication destroys the connection of the sign with its referent and sends us to another hyperreal reality different from the real world. In the films by Tarkovsky, we still see some representation of the realistic world. But when another director borrows from the films by Tarkovsky, then the new film does not represent reality at all because its image 
refers the viewer to the original source of the borrowing (the films by Tarkovsky) and not to the representation of reality. The referent of the real world is destroyed. The source film itself becomes the referent, but the object of reality does not. Thus we approach a situation of hyperrealism. Fredric Jameson confirms this hypothesis. He claims that borrowings from earlier works indicate a lack of opportunity for contemporary artists to represent modernity: "we were unable today to focus our own present, as though we have become incapable of achieving aesthetic representations of our own current experience" [Jameson 1983, 117].

My assumption is best seen in films-remakes. A remake is the preservation of the main plot developments from the original film with a modification or addition of its own special characteristics and properties: changing the time of action, scene of action, cultural background where the events of the remake develop, aesthetics of the film, etc. As a rule, primary source films are the tremendously successful films which became the cultural heritage - clichés that are well known to the audience in detail, i.e., mental images or formulas. For example, the South Korean film Oldboy (2003) directed by Park Chan-wook became a cult heritage of world cinema and won the Grand Prix at the 2004 Cannes Film Festival. All the events of the film take place in South Korea at the background of Korean cultural tradition: clothing, food and martial arts.

As a rule, there is a large temporal difference between the original source and its "secondary" work - a remake. Jameson points out that transferring the action to contemporary time muffles that time and actualizes the nostalgic state, thereby plunging the viewer into escapism. At the same time the narration in the new film: "does not represent our historical past so much as they represent our ideas or cultural stereotypes about that past" [Jameson 1983, 117-118]. So 10 years later the remake with the same name Oldboy (2013) directed by Spike Lee was released in Hollywood. The action takes place in contemporary America. The film's emphatically postmodern aesthetic is based on contemporary American-European culture. The original storylines were retained in the remake.

For remake viewers, the happening on the screen refers to the original film (referent) which they already know well. This is how the situation of hyperreality arises in the remake. Viewers already "absorbed" the well-known archetypes and plot moves of the original film and begin to compare them with the new versions of the known offered in the remake. It turns out that viewers see something new introduced by the author of the remake in the already known. This situation is defamiliarization by Shklovsky mentioned above. 
When viewers see in the remake the plot formulas they know from the original film, they feel stability and security for themselves since they know how it is going to end. That is why watching remakes is so popular, although they are often artistically inferior to their original sources. This is confirmed by the film Oldboy. The remake received very low ratings from critics and viewers.

\section{Clichés in video games}

The formulaicity as a genre characteristic is very vividly expressed in video games. All stages of the game represent a certain formula. Performing the first stage we move on to the second stage and the same formula is waiting for us with a different actual content. And so on until the end of the game. The formula also defines the genre of the video game: action, shooter, simulation, sports, role-playing, quest, etc. Each video game genre listed is based on a single formula that is specific to one particular genre. For example, one formula is used for all action video games, another formula is used for the entire shooter genre. In video games, we can find many scenes taken from the movies. One of the world's leading video game designers, Hideo Kojima, who created the Metal Gear series of games, said that he himself is $70 \%$ film. This can be seen in his video games, where we meet familiar characters from films as well as entire scenes. Video game researchers have identified 19 films that were sources for Hideo Kojima's borrowings. I define these borrowings as formulas for representing characters or plot moves, according to the definition of Cawelti's formula.

Borrowings from films are sometimes entire scenes and episodes. For example, an entire scene in the video game Conker's Bad Fur Day (2001) by Rare is taken from film The Matrix (1999): a shootout scene. Both the plot of the film and the style of music were copied in the parodic quotation for the video game. In addition, four years later, the remake of the game was released for the Xbox called: Conker: Live \& Reloaded (2005). At the same time, there are also video games based on the narrative from the trilogy of films The Matrix - Enter the Matrix (2003), The Matrix: Path of Neo (2005). All these replays from The Matrix films are well known to the viewer and they became cultural clichés or mental images formulas. The reasons why video game authors resort to borrowing are similar to those for remakes and the works by Quentin Tarantino, Lars von Trier, and other famous postmodern filmmakers.

The workflows and technologies greatly influence the aesthetics and storytelling of video games. Therefore, in video games, the hyperrealism of virtual world, the immersiveness and escapism of the video game 
player are very distinctly expressed. The immersiveness in video games is very deep compared to other audiovisual arts.

\section{Clichés in video art and audiovisual installations}

Other audiovisual arts I want to talk about are video art and audiovisual installations. Antonio Geusa classifies video art into three groups related to the aesthetic approach: performative video, when the camera is facing the artist him-/herself; activist video, when the camera is turned from the artist into the outside world in order to analyze socio-political, feminist and philosophical issues. This direction is close to documentary activist cinema and acts as an alternative to television. The third direction is a formal approach ${ }^{1}$ when the artist focuses on the capabilities of the tool itself, i.e., camera, studying the possibility of video art language and technical capabilities of technological process in video art [Geusa 2005]. The development of video art led to the blurring of boundaries between video art and audiovisual installation in which elements of video art became an integral part of this art.

Speaking about the first two classifications of video art that Geusa mentions, one can point to a common element for them: the conceptual approach. Many of the early and well-known video artists were associated with the conceptual art movement: Nam June Paik, Vito Acconci, Joan Jonas, Bruce Nauman, Bill Viola, and many others. In conceptual art, the concept as the transmission of an idea is the most important; therefore, conceptual art is an artistic gesture of the author. The video camera became a favorite tool of conceptual artists who, with its help, analyzed the influence of screen culture (television, advertising, etc.) on viewers' perception, promotion of feminist ideas in video art, philosophical reflections, as well as narcissistic studies of "oneself" (as a person) through a psychoanalytic mirror in the form of a video camera.

Initially, video artists set themselves the goal of destroying the canons and norms of traditional art (primarily narrative cinema and theater), the media (television and advertising), which exerted tremendous pressure on a person. Video art is an existential stream reproduced with the help of technology, opposed to cinema as a kind of a narrative structure. It is a stream of video sequences without a clear linear narrative construction as if it were accidentally composed by itself. For this, very often, video art was filmed in one shot without editing. Another goal of video art, put forward by video artists, was to bring art closer to life and blur the boundaries between them to penetrate into all spheres

\footnotetext{
${ }^{1}$ I will not discuss this third direction of video art in this article, because it is more related to the Parry-Lord theory, which I do not consider in my study.
} 
of human life, using screen moving images. Despite all of these stated goals, ways to achieve them were often based on borrowing.

So Vito Acconci, in his famous work Centers (1971), where he holds a straight hand with an index finger in front of the camera for 23 minutes and looks into the camera himself (see Figure 2), refers us to concept posters from the period starting from WWI to WWII inclusive. See Figures 3 and 4 . These propaganda posters had a strong impact on people.

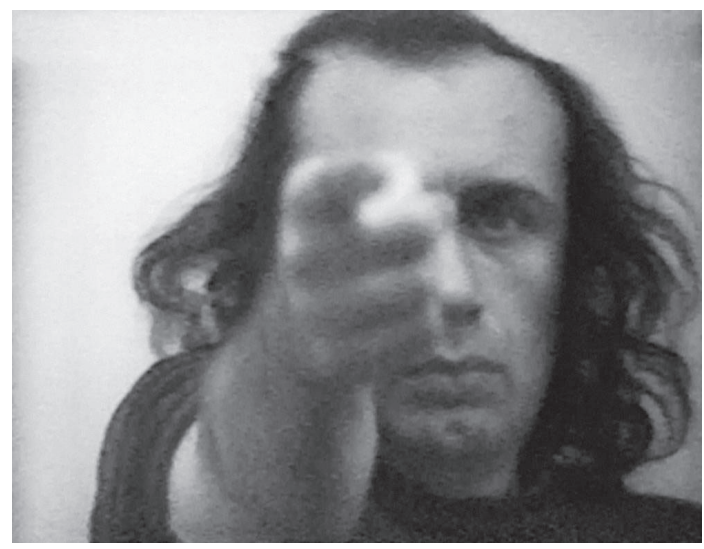

Fig. 2. Vito Acconci. Centers (1971). Video art, 22 min., 28 sec.

Photo from open sources: https://www.metmuseum.org/art/collection/search/292045

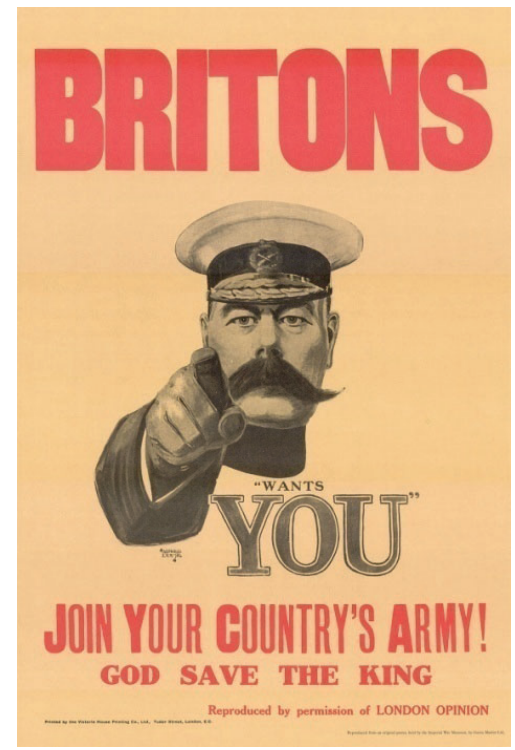

Fig. 3. Alfred Leete. Lord Kitchener - poster (1914).

Photo from open sources: https://www.stneotsmuseum.org.uk/wp-content/uploads/2018/11/1-4-g.jpg 


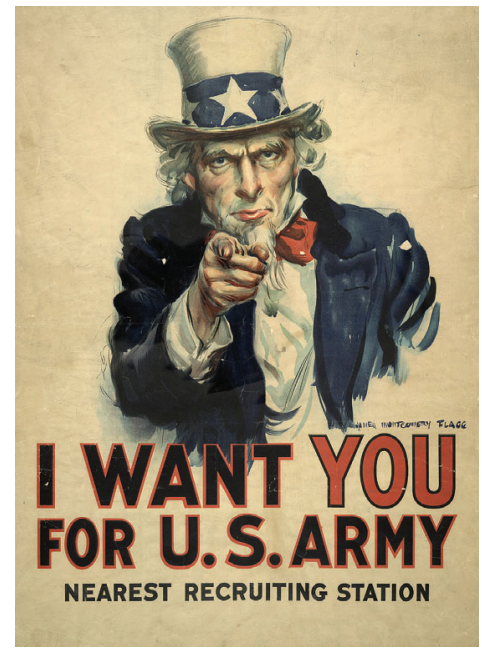

Fig. 4. James Montgomery Flagg. I Want You for U.S. Army - poster (1917). Photo from open source: https://payload.cargocollective.com/1/0/4579/12920296/ JamesMontgomeryFlagg_IWantYou1917_IllustrationChronicles_1500.jpg

As we can see from the given examples, the composition of Acconci's work is borrowed from the art of propaganda posters. The concept used in the posters was supposed to evoke (it did very well) certain strong feelings in the addressee: responsibility for their country, patriotism: i.e., deep introspection. Acconci uses the same concept, so his work also evokes deep introspection in the viewer. The difference is that introspection in the posters was aimed at a specific area - recruitment, while in the video art of Acconci we cannot see any specific desired author's direction - the result. Thus, the author of the video art points out the need to make an introspection for the entire human essence of the viewer. We can summarize that such concepts, even from different arts and time periods, work the same way for the addressee. And so they can be defined as clichés or formulas.

The Korean video artist Nam June Paik is considered to be the founder of video art. In 1965, Paik purchased a Sony Portapak camcorder and was the first to create a video work - thus the era of video art was started. Paik was part of the Fluxus group and was heavily influenced by John M. Cage, whom he met in 1958. So, for example, the principle of prepared piano by John Cage, its essence lay in the idea that various objects were added to an ordinary piano, which created all sorts of sounds that did not correspond to the given musical instrument. As a result, the sound palette of the piano expanded. Paik decided to use this "prepared" principle using a television signal. So, in March 1963, in Germany, at the Galerie Parnass in the city of Wuppertal at the 
international music festival Exposition of Music-Electronic Television, Paik created an installation of four prepared pianos, twelve televisions and other improvised things. He changed the setting of these TVs, so that the usual electronic signal underwent distortion during its passage, which ultimately created a vertical image, not a horizontal one. The image on the TVs was synchronized with the microphone. And when the viewer spoke into the microphone, the images changed according to the sound changes and took the form of visual abstractions that existed only for a moment, like sounds heard by a microphone. The stream of electrons momentarily left a trail on the television screen as evidence of its presence thus testifying to the existential moment and nothing more. In this way, Nam June Paik expanded the capabilities of the television and the entire television medium. Again, we see here the use of the same concept in different arts, which caused similar feelings of surprise in the addressee, both in music and in television medium.

Paik's conceptual audiovisual art was a huge success. Paik often used well-known symbols (such the United States map, Buddha sculpture, etc.) and introduced these symbols into situations that were not natural for them. That aroused the viewer's shock interest. This way the artist wanted to bring art into the everyday world of the viewer. It was the proclamation made by video artists at the initial stage of this art's development.

Philosophical contemplations are also present in the works of the Korean artist. In his work TV Buddha (1974), the Buddha sculpture was placed facing a television camera, and the Buddha sculpture image is shown on the monitor (which is located between the camera and the sculpture) in real time. (See Fig. 5). It is not a reflection, but it is a reproduction of oneself. The technical image acts as a window to the world of meditation, involving the viewer into a kind of play of temporalities; Paik makes the viewer experience the non-identity of the artistic and real time.

Today, we can see the development of this concept in the very process of shooting video selfies and using it as some kind of an inner gesture of the author, although, of course, selfie videos do not raise such philosophical questions that we see in the work of the Korean media artist. But technically, it is a continuation of Paik's concept. Here we see a cliché created by an artist that is used by everyone. This is what Oleg Aronson meant talking about "film geniuses".

Summing up the performance direction of video art and video installation, I can say that with all the desire to destroy the canons and clichés of traditional art, media artists used borrowings that can be defined as formulas and mental images of visual culture. The sources of borrowing were works of art well known to the viewer or philosophically and socially significant mental images or concepts. 


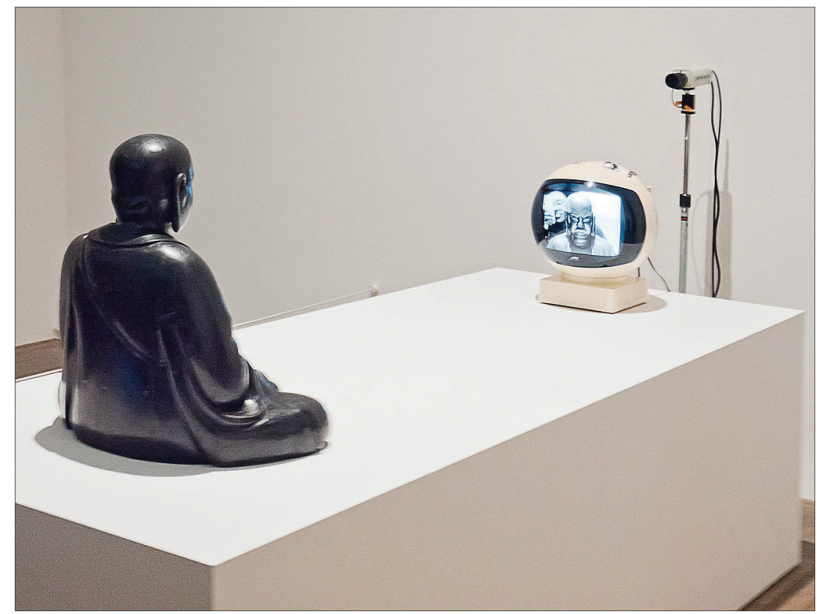

Fig. 5. Nam June Paik. TV Buddha (1974).

Photos from (C) Flickriver: https://miro.medium.com/max/499/1*Rdue6C7RiocbZQNsM4vrXg.jpeg

The second direction in video art - activist or documentary (the camera is aimed at the world) - is based even more on the use of sociocultural clichés. These clichés are objects of study with the purpose to destroy them and show their insignificance. The American art group Ant Farm (1968-1978), which was very popular in America and known all over the world, created installations, happy ends and performances as political criticism. They recreated major media events in the American media and emphasized the failure of media profanations in the society of spectacle (the term by Guy Debord is particularly appropriate here), which at the same time exerted tremendous pressure on American society. In the Media Burn work (1975), the authors confront two America's most powerful symbols: car and television. This video installation is full of all sorts of television clichés: the aesthetics of TV news and information programs; a parody at receiving interviews from the scene about the role of television for interviewees; it shows the event of celebrating the US Independence Day - July 4, 1975, and a 1959 Cadillac Eldorado Biarritz convertible, symbolizing the luxurious American life. At the end of the installation, this car crashes into a wall of burning TVs and successfully breaks through that wall. The congestion of many people who came to see the event was also demonstrated. There is given a parody of the official speech by President John F. Kennedy, who was killed more than ten years before the demonstration. During this performance, parody accents are made about how much the security service guards him. At the same time, everyone knows the fate of Kennedy, whom the guards could not save from being murdered. Kennedy is taking the floor on 
the podium, which is built in the form of a TV, thereby emphasizing the media nature of what is happening. Kennedy's speech does not have any thoughtful content. All kinds of topics that have no connection with each other are tied together. This emphasizes the senselessness of such speeches. It is shown how TV people are filming the president's speech. After the speech, the president descends from the podium, amid the joyful shouts and whistles of the people present, gets into the Cadillac and leaves the scene. Then there appears the Cadillac, which will break through the wall of TVs. There are two racers standing on it, they will be driving the car during the performance. The American flag is shown as a symbol of the strength and progress of the United States, the anthem of America is played and the racers are standing on the car like athletes singing the anthem before the match. We skip some enumerated actions. As a result, the racers successfully break through the wall of the TVs, and then show how they are greeted by the public as winners. All scenes are filmed in a typical television manner, and the behavior of all participants is also shown in typically accepted norms (mental clichés). All this is finally ridiculed, and their inability is shown in fact. At the same time, the viewer is given an idea of how all these norms in the media space "brainwash" the Americans. As a result, we see an artistic gesture against the sociopolitical dictatorship of the media and authorities.

As we can see, the use of borrowings or certain narrative moves (formulas) is intrinsic to all postmodern audiovisual (and not only audiovisual) art. Jameson, speaking of postmodern art, points to a characteristic property of the contemporary artist: "seizes on their idiosyncrasies and eccentricities to produce an imitation which mocks the original" [Jameson 1983, 113].

\section{Digital component of contemporary audiovisual art}

Certain changes have taken place in audiovisual art with the coming of digital standard. New media are communication tools that are based on computer code. There is a famous expression by Marshall McLuhan: "The medium is the message". This means that the type of media determines the properties of messages. Television, radio, newspaper characterize the properties of messages transmitted with their help. The situation is completely different in new media.

In digital media, the ultimate meaning of the information message is not formed at the levels of the media themselves, such as file format, file content or text file content. The meaning depends on the software of the 
program in which we are viewing this file. It turns out that the meaning depends on the interface of the program we use to play the file or read its content. In the digital source itself, as a file, information is not formulated, i.e., "none" [Manovich 2012, 4]. An example is the use of a video editor for video editing. A graphic photo file that gets processed in the video editor becomes a video file with a video format. The same happens with the titles and the sound. We see that the final meaning is formed when working with the program interface.

If the meaning depends on the interface, then the properties of the interface should be investigated. The interface is a general mechanism of the program for managing digital information. One interface can be used in different programs. If one interface or its principle of operation can be used in different programs, then we can say that the interface in this case acts in the role of a cliché (formula) in relation to digital information. If we continue talking about the video editor, then we can say that they are all basically built on the same principles. As an example, we can say that all these video editors have $80 \%$ identical basic filters. This means that we change video information using the same clichés (filters) in different programs. The same thing happens in graphic editors.

The huge role of the interface in digital audiovisual arts is primarily manifested in video games and audiovisual installations. In video games, the interface defines all the aesthetic and functional possibilities of the game, artistic space and time, as well as capabilities and characteristics of the acting characters and the player. For example, Gameplay depends on the capabilities of the video game interface and its game engine. It often happens that the basic interfaces capabilities of different games also duplicate each other, thus it is possible to point out the clichés of the permissible actions by the player or character. In audiovisual installations, the interface is the main means of the expression plane and the content plane.

\section{REFERENCES}

Aronson 2003 - Aronson, O. (2003). Metacinema. Ad marginem. (In Russian).

Aronson 2013 - Aronson, O. (2013). Cinema is now a kind of icon of the secularized world. Theory \& Practice, 4. https://theoryandpractice.ru/ posts/6766-aronson (In Russian).

Baudrillard 1993 - Baudrillard, J. (1993). Symbolic Exchange and Death. Sage Publications. 
Cawelti 1976 - Cawelti, J. G. (1976). Adventure, mystery and romance: Formula stories as art and popular culture. English transl. University of Chicago Press.

Deleuze 1986 - Deleuze, G. (1986). Cinema 1. The movement-image. English transl. University of Minnesota Press.

Deleuze 1989 - Deleuze, G. (1989). Cinema 2. The timeimage. English transl. University of Minnesota Press.

Eco 1984 - Eco, U. (1984). Role of the reader: Explorations in the semiotics of texts. Indiana University Press.

Geusa 2005 - Geusa, A. (2005). Video production and art community. Historical parallels between the USA and Russia. Moscow Art Magazine, 58/59. http://xz.gif.ru/numbers/58-59/videotvorchestvo/view_ print (In Russian).

Jameson 1983 - Jameson, F. (1983). Postmodernism and consumer society. In H. Foster (Ed.), The anti-aesthetic: Essays on postmodern culture. Bay Press.

Lord 1971 - Lord, A. B. (1971). The Singer of Tales. Harvard University Press. Lotman 1977 - Lotman, J. (1977). The structure of the artistic text. English transl. University of Michigan.

Lotman, Tsivyan 1984 - Lotman, J. \& Tsivyan, Yu. (1984). SVD: genre of melodrama and history. In M. O. Chudakova, E. A. Toddes, \& Yu. G. Tsivyan (Eds.), Tynyanov collection. The first Tynyanov readings. Vol. 1 (pp. 46-78). Zinatne. (In Russian).

Lotman, Uspensky 1998 - Lotman, J. \& Uspensky, B. (1998). Convention in art. In J. Lotman, On Art (pp. 374-377). Iskusstvo-SPB. (In Russian).

Manovich 2012 - Manovich, L. (2012). Media after software. https://www. academia.edu/9812905/Media_After_Software

Parry 1971 - Parry, M. Studies in the Epic Technique of Oral VerseMaking. I. Homer and Homeric Style (HS). The making of Homeric verse: the collected papers of Milman Parry. Oxford. 1971. pp. 266-324.

Propp 1984 - Propp, V. (1984). Theory and History of Folklore (pp. 16-38). English transl. University of Minnesota Press.

Tarantino 1994 - Tarantino, Q. (1994). Interview. Empire, 65 (Nov.), 86-89.

Zvyagintsev 2014 - Zvyagintsev, A. (April 17, 2014). The social dimension in my new films is not a strategy - interviews. Colta. https:// www.colta.ru/articles/cinema/2936-andrey-zvyagintsev-sotsialnoeizmerenie-v-moih-novyh-filmah-ne-strategiya (In Russian).

Материал поступил в редакциию 02.10.2020 